\title{
Cytologic alterations in the oral mucosa after chronic exposure to ethanol
}

\section{Alterações citológicas na mucosa bucal após exposição crônica ao etanol}

\author{
Sílvia Regina de Almeida Reis* \\ Alexandre Ribeiro do Espírito Santo** \\ Miguel Gustavo Setúbal Andrade*** \\ Moysés Sadigursky****
}

\begin{abstract}
The effects of ethanol alone on the oral mucosa are still poorly understood, especially because there are few non-smoking chronic consumers of alcoholic beverages. The aim of this study was to evaluate the frequency of micronucleus, abnormal nucleus/cytoplasm ratio, pyknosis, karyorrhexis and karyolysis in exfoliated cells from the buccal mucosa and from the lateral border of the tongue in 36 non-smoker alcoholics (ethanol group) and 18 non-smokers and non-drinkers (control group). The Papanicolaou method was used. Since alcoholics generally have hepatobiliary involvement, the association between serum gamma-glutamyl transpeptidase (GGT) and some of the analyzed oral mucosa alterations was also investigated. The ethanol group showed a significant increase in the frequency of all alterations analyzed in the tongue cells when compared with the control group $(\mathrm{p}<0.01$; MannWhitney). However, the presence of these changes in buccal mucosa cells was not statistically significant ( $p>0.05$; Mann-Whitney). In the ethanol group, the correlation between serum GGT and the frequency of micronucleus and abnormal nucleus/cytoplasm ratio in oral mucosa cells was not significant ( $p>0.05$; Spearman). In conclusion, chronic exposure to ethanol may be associated with carcinogenic cytologic changes in the oral mucosa, even in the absence of tobacco smoking. These alterations were not correlated with hepatobiliary injury.
\end{abstract}

DESCRIPTORS: Cytology; Mouth mucosa; Ethanol; Carcinogens.

RESUMO: Os efeitos do etanol isoladamente sobre a mucosa bucal permanecem pouco esclarecidos, sobretudo devido ao baixo número de não-fumantes consumidores crônicos de bebidas alcoólicas. O objetivo deste estudo foi avaliar as freqüências de micronúcleo, relação núcleo/citoplasma anormal, picnose, cariorrexe e cariólise em células esfoliadas da mucosa jugal e do bordo lateral da língua de 36 alcoólatras não-fumantes (grupo etanol) e 18 abstêmios de álcool e fumo (grupo controle). O método de Papanicolaou foi utilizado. Uma vez que indivíduos alcoólatras geralmente apresentam comprometimento hepatobiliar, a associação entre gama-glutamil transpeptidase (GGT) sérica e algumas das alterações citológicas analisadas também foi investigada. O grupo etanol mostrou um aumento significativo nas freqüências de todas as alterações investigadas nas células da língua quando comparado ao grupo controle ( $\mathrm{p}<0,01$; Mann-Whitney). No entanto, a presença de tais mudanças na mucosa jugal não foi estatisticamente significante ( $p>0,05$; Mann-Whitney). No grupo etanol, a correlação entre GGT sérica e as freqüências de micronúcleo e a relação núcleo/citoplasma anormal em células da mucosa bucal não foi significativa ( $\mathrm{p}$ > 0,05; Spearman). Conclui-se que o consumo crônico de etanol pode estar associado a alterações citológicas carcinogênicas na mucosa bucal, mesmo na ausência de exposição ao fumo. Tais alterações não apresentaram correlação com o comprometimento hepatobiliar.

DESCRITORES: Citologia; Mucosa bucal; Etanol; Carcinógenos.

\section{INTRODUCTION}

In Brazil, the incidence rates of oral cancer differ substantially in the different areas, and this is possibly due to the local differences in the prevalence of the risk factors ${ }^{7}$. Tobacco smoking has proved to be an independent risk factor for oral cancer development ${ }^{28}$, and exposure to both ethanol and tobacco results in an increase in the incidence of this malignant neoplasm ${ }^{21}$. Some studies appear to confirm that ethanol alone increases the risk for oral cancer ${ }^{6,21,27}$. However, as ethanol

\footnotetext{
* PhD, Department of Propaedeutics and Integrated Clinic, School of Dentistry; ****PhD, Pathologic Anatomy Department, School of Medicine - Federal University of Bahia.

** MS, Department of Morphology, School of Dentistry of Piracicaba, State University of Campinas.

*** MD, Basic Science Department, School of Dentistry, Foundation for the Development of Science.
} 
Reis SRA, Espírito Santo AR, Andrade MGS, Sadigursky M. Cytologic alterations in the oral mucosa after chronic exposure to ethanol. Braz Oral Res 2006;20(2):97-102.

itself is not carcinogenic, the exact mechanisms behind ethanol-associated oral carcinogenesis remain poorly understood ${ }^{9}$. In addition, smoking and ethanol consumption are almost invariably coexisting factors, making it difficult to assess the individual effects of these factors ${ }^{27}$.

Excessive consumption of alcoholic beverages like "cachaça", a beverage derived from sugar-cane, is an important cultural risk factor in the aetiology of oral cancer in Brazil2 ${ }^{20,22}$. The aim of this study was to evaluate the frequency of micronucleus, abnormal nucleus/cytoplasm ratio, pyknosis, karyorrhexis and karyolysis in exfoliated cells from the lateral border of the tongue and from the buccal mucosa of non-smoking chronic ethanol consumers from Salvador/BA-Brazil. Since alcoholics generally have hepatobiliary involvement, the association between some of the analyzed oral mucosa alterations and serum gamma-glutamyl transpeptidase was also investigated.

\section{MATERIALS AND METHODS}

The ethanol group consisted of 36 non-smoker alcoholic individuals selected from among the patients attending the detoxification centre of Ana Nery Psychiatric Hospital (Salvador/BA-Brazil), whose Ethics Committee approved the study. The control group comprised 18 individuals who were alcohol and tobacco abstainers, also selected in Salvador/BA-Brazil from religious groups that traditionally abstain from these chemicals. Informed written consent was obtained from all the participating patients and abstainer volunteers. In the 36 hospital patients, ethanol consumption was determined by a questionnaire applied to each volunteer. Blood samples $(10 \mathrm{ml})$ were collected from all subjects in the morning, within $48 \mathrm{~h}$ after being admitted, for the purpose of measuring serum levels of gamma-glutamyl transpeptidase (GGT), glutamic-oxaloacetic transaminase (GOT) and glutamic-pyruvic transaminase (GPT). After clinical examination of the oral cavity, alcoholics and abstainers rinsed their mouths with distilled water to remove debris from saliva and mucosa surface. Next, exfoliated cells from the lateral border of the tongue and from the buccal mucosa were obtained with a cytobrush (Canadian Medical Brush Inc., Ontario, Canada) and placed in a test tube containing physiological saline solution. Cells of all individuals were collected from oral mucosa sites without ulcerations and other lesions. The physiological saline solution containing exfoliated cells was centrifuged at $1,500 \mathrm{rpm}$ for $10 \mathrm{~min}$ and the supernatant was discarded. Immediately, the cells were fixed and transferred directly onto a precleaned microscopic slide and allowed to air-dry for $24 \mathrm{~h}$. The slides were then stained by the $\mathrm{Pa}-$ panicolaou method and coverslipped.

A minimum of 500 intact epithelial cells from each sample were screened for the presence of micronucleus, abnormal nucleus/cytoplasm ratio, pyknosis, karyorrhexis and karyolysis. Analysis was performed in a blind test. Extrachromosomal cytoplasmic DNA fragments were counted as micronuclei under the following conditions: 1 . intact main nucleus and cytoplasm; 2 . diameter $1 / 3$ of the main nucleus; 3 . same staining and texture as the main nucleus; and 4. micronuclei were in the same focal plane as the main nucleus. The nucleus/cytoplasm ratio was considered to be abnormal when nuclear area was larger than $1 / 3$ of cytoplasmic area.

The results were expressed as mean \pm standard deviation (SD), or median and interquartile interval (IQI). Differences between ethanol and control groups were determined using the Mann-Whitney test. Spearman's rank correlation was used to investigate the association between serum GGT and the occurrence of micronucleus and abnormal nucleus/cytoplasm ratio in tongue and buccal mucosa exfoliated cells from non-smoker alcoholics. $\mathrm{p}<0.05$ and $\mathrm{p}<0.01$ were taken as the levels of significance.

\section{RESULTS}

The ethanol and control groups were compared by making an assessment of gender, age, serum GGT, GOT/GPT ratio, and frequencies of micronucleus, abnormal nucleus/cytoplasm ratio, pyknosis, karyorrhexis and karyolysis in exfoliated cells from the lateral border of the tongue and from the buccal mucosa. All subjects in both groups were men. The mean age was 42.9 years $(\mathrm{SD}=9.3)$ for the ethanol group and 42.4 years $(\mathrm{SD}=10.4)$ for the control group, without significant statistical difference $(\mathrm{p}=0.8674)$. With regard to the alcoholic individuals, a median weekly ethanol intake of $2,571.3 \mathrm{ml}$ (IQI $=2,433.2$ ) was observed. They had been exposed for a median of 25 years $(\mathrm{IQI}=14.5)$.

A significant difference between the examined population groups was noted when serum GGT and GOT/GPT ratio were analyzed (Table 1). The median values of these variables were significantly higher 
Reis SRA, Espírito Santo AR, Andrade MGS, Sadigursky M. Cytologic alterations in the oral mucosa after chronic exposure to ethanol. Braz Oral Res 2006;20(2):97-102.

TABLE 1 - Serum GGT and GOT/GPT ratio distribution of the examined population groups $(n=54)$.

\begin{tabular}{c|c|c|c|c|c}
\hline \hline \multirow{2}{*}{ Groups } & \multirow{2}{*}{$\mathrm{n}$} & \multicolumn{2}{|c|}{ GGT(UI/1) } & \multicolumn{2}{c}{ GOT/GPT } \\
\cline { 3 - 6 } & & Median & IQI & Median & IQI \\
\hline Ethanol & 36 & 86.5 & 265 & 1.48 & 1.16 \\
\hline Control & 18 & 21.5 & 15 & 1.10 & 0.31 \\
\hline \multicolumn{2}{c|}{$\mathrm{p}$ value } & \multicolumn{2}{c}{$0.000^{*}$} \\
\hline
\end{tabular}

IQI: interquartile interval. *Mann-Whitney test $(\mathrm{p}<0.01)$.

in the chronic ethanol consumer group (Table 1). A GOT/GPT ratio greater than 2:1 was observed in $41.6 \%$ of non-smoker alcoholics (Graph 1).

In relation to exfoliated cells from the lateral border of the tongue, there was a significant rise in the median frequency of each anomaly in the ethanol group when compared to the control group (Table 2).

With regard to buccal mucosa, the median frequencies of the cytologic alterations were high in the ethanol group compared with the control group, but this was not statistically significant (Table 3).

The Spearman's rank correlation analysis showed no significant correlation between variation in serum GGT values and frequency of micronuclei in exfoliated cells from the lateral border of the tongue $(\mathrm{n}=36, \mathrm{r}=-0.241, \mathrm{p}=0.155)$ and from the buccal mucosa ( $\mathrm{n}=36, \mathrm{r}=0.110, \mathrm{p}=0.521)$ of non-smoker alcoholic subjects. There was also no significant correlation between variation in serum GGT levels and frequencies of abnormal nucleus/ cytoplasm ratio in cells from the lateral border of the tongue $(\mathrm{n}=36, \mathrm{r}=-0.3344, \mathrm{p}=0.0462)$ and from the buccal mucosa $(n=36, r=-0.0205$, $\mathrm{p}=0.9040)$.

\section{DISCUSSION}

The most important risk factors for oral cancer development are smoking and alcohol intake ${ }^{3,23}$. Since these two factors are almost invariably coexistent, it is difficult to assess their individual effects ${ }^{27}$. Fioretti et al. ${ }^{6}$ (1999), in a retrospective study, observed that alcoholic beverage drinking was the major risk factor for oral and pharyngeal cancer in persons that have never smoked. There are several mechanisms by which ethanol may have an influence on the oral mucosa. Among these are the oxidizing activity leading to changes by direct injury to DNA, and increased carcinogen penetration across the oral mucosa, by raising carcinogen solubility or perhaps by increasing mu-

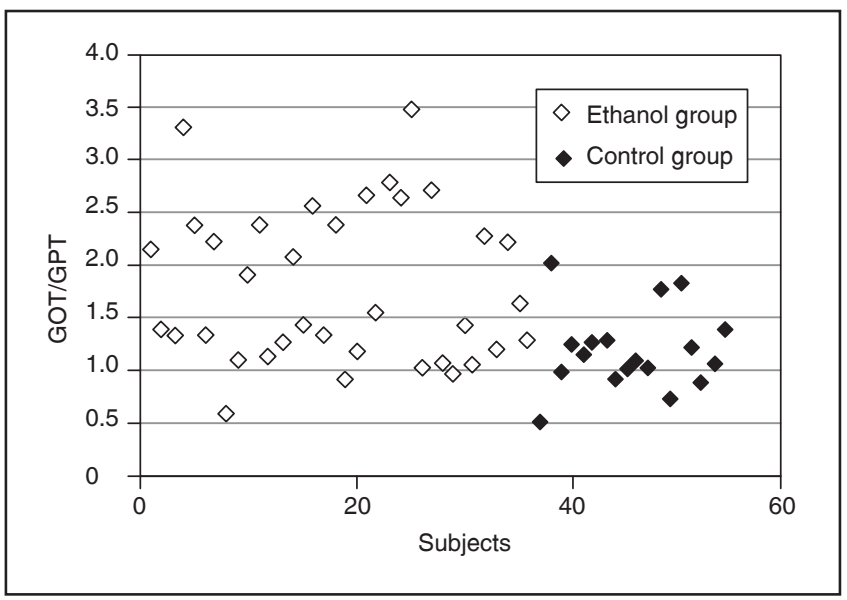

GRAPH 1 - GOT/GPT ratio distribution of the examined population groups $(\mathrm{n}=54)$.

cosa permeability ${ }^{12,27}$. Ethanol activity associated with oral carcinogenesis generally occurs when the daily ethanol intake exceeds $45 \mathrm{ml}^{29}$. In the present study, alcoholic subjects with clinically normal oral mucosa had a median daily ethanol intake of $365 \mathrm{ml}(\mathrm{IQI}=328.4)$ and a median exposure period of 25 years (IQI $=14.5$ ).

There is increasing evidence that acetaldehyde, the first metabolite of ethanol, is responsible for the major part of the carcinogenic potency of ethanol ${ }^{9,16}$. Acetaldehyde has been shown to be highly toxic, mutagenic and carcinogenic in different cell cultures and animal models ${ }^{5,9}$. Homann et al. ${ }^{9}$ (1997) demonstrated increased salivary acetaldehyde levels even after ingestion of moderate amounts of ethanol. This could allow significant acetaldehyde accumulation in oral tissues during chronic ethanol consumption and may explain some of the cytologic anomalies in the oral mucosa of non-smoker alcoholics. Several researchers quote these anomalies, and include the following among them: increase in the nuclear area ${ }^{13}$, epithelial atrophy due to a decrease in basal cellular size $^{14}$, dysplastic changes with keratosis and increased number of mitotic figures ${ }^{15}$. In the pres- 
Reis SRA, Espírito Santo AR, Andrade MGS, Sadigursky M. Cytologic alterations in the oral mucosa after chronic exposure to ethanol. Braz Oral Res 2006;20(2):97-102.

TABLE 2 - Distribution of the cytologic anomalies found on the lateral border of the tongue in the examined population groups $(\mathrm{n}=54)$.

\begin{tabular}{|c|c|c|c|c|c|c|c|c|c|c|c|}
\hline \multirow[t]{2}{*}{ Groups } & \multirow[t]{2}{*}{$\mathrm{n}$} & \multicolumn{2}{|c|}{$\begin{array}{c}\text { Pyknosis } \\
(\%)\end{array}$} & \multicolumn{2}{|c|}{$\begin{array}{c}\text { Karyorrhexis } \\
(\%)\end{array}$} & \multicolumn{2}{|c|}{$\begin{array}{c}\text { Karyolysis } \\
(\%)\end{array}$} & \multicolumn{2}{|c|}{$\begin{array}{c}\text { Abnormal } \\
\text { nucleus / } \\
\text { cytoplasm ratio } \\
(\%)\end{array}$} & \multicolumn{2}{|c|}{$\begin{array}{l}\text { Micronucleus } \\
(\%)\end{array}$} \\
\hline & & Median & IQI & Median & IQI & Median & IQI & Median & IQI & Median & IQI \\
\hline Ethanol & 36 & 3.8 & 3.8 & 1.2 & 1.8 & 2.0 & 2.6 & 0.2 & 0.2 & 0.2 & 0.2 \\
\hline Control & 18 & 1.1 & 3.0 & 0.0 & 0.4 & 0.6 & 1.0 & 0.0 & 0.2 & 0.0 & 0.2 \\
\hline \multicolumn{2}{|c|}{$\mathrm{p}$ value } & \multicolumn{2}{|c|}{$0.018^{*}$} & \multicolumn{2}{|c|}{$0^{* *}$} & \multicolumn{2}{|c|}{$0.001^{* *}$} & \multicolumn{2}{|c|}{$0.002 * *$} & \multicolumn{2}{|c|}{$0.002 * *$} \\
\hline
\end{tabular}

IQI: interquartile interval. *Mann-Whitney test $(\mathrm{p}<0.05) .{ }^{* *}$ Mann-Whitney test $(\mathrm{p}<0.01)$.

TABLE 3 - Distribution of the buccal mucosa cytologic anomalies in the examined population groups (n = 54).

\begin{tabular}{|c|c|c|c|c|c|c|c|c|c|c|c|}
\hline \multirow[t]{2}{*}{ Groups } & \multirow[t]{2}{*}{$\mathrm{n}$} & \multicolumn{2}{|c|}{$\begin{array}{c}\text { Pyknosis } \\
(\%)\end{array}$} & \multicolumn{2}{|c|}{$\begin{array}{c}\text { Karyorrhexis } \\
(\%)\end{array}$} & \multicolumn{2}{|c|}{$\begin{array}{c}\text { Karyolysis } \\
(\%)\end{array}$} & \multicolumn{2}{|c|}{$\begin{array}{c}\text { Abnormal } \\
\text { nucleus / } \\
\text { cytoplasm ratio } \\
(\%)\end{array}$} & \multicolumn{2}{|c|}{$\begin{array}{c}\text { Micronucleus } \\
(\%)\end{array}$} \\
\hline & & Median & IQI & Median & IQI & Median & IQI & Median & IQI & Median & IQI \\
\hline Ethanol & 36 & 1.8 & 2.3 & 0.6 & 0.6 & 1.7 & 2.7 & 0.2 & 0.3 & 0.1 & 0.2 \\
\hline Control & 18 & 1.3 & 2.4 & 0.2 & 1.0 & 1.6 & 2.0 & 0.0 & 0.0 & 0.0 & 0.0 \\
\hline \multicolumn{2}{|c|}{$\mathrm{p}$ value } & \multicolumn{2}{|c|}{$0.275^{*}$} & \multicolumn{2}{|c|}{$0.545^{*}$} & \multicolumn{2}{|c|}{$0.267 *$} & \multicolumn{2}{|c|}{$0.053 *$} & \multicolumn{2}{|c|}{$0.071 *$} \\
\hline
\end{tabular}

IQI: interquartile interval. *Mann-Whitney test $(\mathrm{p}>0.05)$.

ent study, alcoholic subjects did not have clinical alterations in the oral mucosa. Nevertheless, cytologic changes were observed, such as pyknosis, karyorrhexis and karyolysis in increased numbers of tongue and buccal mucosa cells. These features do not indicate carcinogenic action and may be understood as induction of the keratinization process, with the purpose of protecting non-keratinized oral mucosa from injury caused by ethanol. Increased incidence of abnormal nucleus/cytoplasm ratio was also noticed in the exfoliated cells of the ethanol group. This finding is probably associated with oral carcinogenesis and corroborates previous investigations that reveal statistically significant reduction in mean cytoplasmic area of cells taken from normal buccal mucosa of alcohol-dependent patients ${ }^{19}$. However, in the present study the nucleus/cytoplasm ratio was not determined by cytomorphometry. Exfoliative cytology of established oral cancers exhibits polyploid DNA profiles and reduction in cytoplasmic area ${ }^{4}$. Since polyploid DNA profiles were seen only in established oral cancer results, more subtle changes in DNA and nuclear morphologic characteristics may be observed in clinically normal mucosa, and may be just as important for detecting future cancer in susceptible patients, as polyploidy is for detecting cancer ${ }^{17}$. Micronucleus assay is a technique that may detect subtle changes. In the present study, increased incidence of micronuclei was detected in the group of chronic non-smoker ethanol consumers.

Since important cytologic alterations related to carcinogenesis occur mainly in deeper layers of oral mucosa, one of the limitations of exfoliative cytology must be considered: obtainment of superficial cells. To overcome this, however, cytobrush use for smears is being encouraged. Experiments conducted by Alberti et al. ${ }^{1}$ (2003) and Ogden et al. ${ }^{18}$ (1992) show that the cytobrush allows cellular representatives to be obtained of all the oral epithelial strata, from non-keratinized young cells (blue cells) to completely keratinized ones (yellow cells with no nucleus). In the present study, the cytobrush was used and cellular types similar to those mentioned above were observed, indicating that deeper cells were successfully collected.

Oral mucosa permeability in different regions of the mouth is an important aspect to consider when analyzing the local effects of ethanol. Nonkeratinized tissues, such as the buccal mucosa and lateral border of the tongue ${ }^{25}$, are shown to be much more permeable than keratinized tissues, such as the palate and gingivae ${ }^{25,27}$. In the present study, two non-keratinized oral mucosa sites were analyzed. When the two groups were compared, the lateral border of the tongue, where oral cancer 
Reis SRA, Espírito Santo AR, Andrade MGS, Sadigursky M. Cytologic alterations in the oral mucosa after chronic exposure to ethanol. Braz Oral Res 2006;20(2):97-102.

is most prevalent ${ }^{24}$, showed a significantly higher frequency of all the investigated cytologic changes. The buccal mucosa showed far fewer significant results, although it is also lined by stratified nonkeratinized squamous epithelium. These findings agree with previous literature reports that point out the buccal mucosa as being a region less exposed to carcinogenic action ${ }^{8}$.

The presence of contaminants, such as polycyclic aromatic hydrocarbons and nitrosamines, is a significant carcinogenic factor in alcoholic beverage $^{26}$. However, it would appear that the total amount of ethanol and the duration of ethanol consumption are more important factors than the type or composition of the alcoholic beverage consumed $^{10,27}$. In the present study, most of the alcoholic subjects mainly drank "cachaça", a beverage with a high ethanol concentration, derived from sugar-cane, generally manufactured in the Northeast region of Brazil. In a previous study, also conducted in Salvador/BA-Brazil by our group, this type of alcoholic beverage was observed to be the one most consumed by individuals who had malignant oral and pharyngeal neoplasms ${ }^{20}$.

Several biochemical tests are useful to assess hepatobiliary involvement. Increased serum GGT levels are usually detected in alcoholic patients, even in the absence of hepatic disease. This can result from microsomal liver enzymes induction by ethanol. In the present study, the median value of serum GGT was significantly higher in the ethanol group compared with the control group. Several

\section{REFERENCES}

1. Alberti S, Spadella CT, Francischone TRCG, Assis GF, Cestari TM, Taveira LAA. Exfoliative cytology of the oral mucosa in type II diabetic patients: morphology and cytomorphometry. J Oral Pathol Med 2003;32(9):538-43.

2. Ávalos E, Martín A, Porras E, Martinez E, Araújo J, Córdoba J, et al. Marcadores biológicos del alcohol em pacientes com carcinoma de laringe. Acta Otorrinolaringol Esp 1998;49(6):465-6.

3. Cohen SM, Ellwein LB. Cell proliferation in carcinogenesis. Science 1990;249(4):1007-11.

4. Cowpe JG, Longmore RB, Green MW. Quantitative exfoliative cytology of abnormal oral smears. J R Soc Med 1988;81(9):509-13.

5. Dellarco VL. A mutagenicity assessment of acetaldehyde. Mutat Res 1988;195(1):1-20.

6. Fioretti F, Bosetti C, Tavani A, Franceschi S, La Vecchia C. Risk factors for oral and pharyngeal cancer in never smokers. Oral Oncol 1999;35(4):375-8.

7. Franco EL, Kowalski LP, Oliveira BV, Curado MP, Pereira $\mathrm{RN}$, Silva ME, et al. Risk factors for oral cancer in Brazil: a case-control study. Int J Cancer 1989;43(6):992-1000. factors, such as acute viral hepatitis, administration of some anticonvulsives and liver metastases, can influence serum GGT levels ${ }^{2}$. None of these clinical conditions were diagnosed in the examined subjects. A GOT/GPT ratio of 2:1 or greater is suggestive of alcoholic liver disease ${ }^{11}$. There was a significant rise in the median GOT/GPT ratio in the ethanol group, and many of the alcoholics showed a GOT/GPT ratio greater than 2:1. These results and the clinical findings were important for corroborating liver injury by ethanol. However, there was no significant correlation between serum GGT levels and the frequency of micronuclei and abnormal nucleus/cytoplasm ratio in the oral mucosa cells of non-smoker ethanol consumers.

\section{CONCLUSION}

The present study indicates that chronic exposure to ethanol may be associated with carcinogenic cytologic changes in the oral mucosa, even in the absence of tobacco smoking. These alterations were more frequent in the lateral border of the tongue and showed no correlation with hepatobiliary injury.

\section{ACKNOWLEDGMENTS}

This work was supported by the Conselho Nacional de Desenvolvimento Científico e Tecnológico - CNPq - Brazil. The participation of all volunteers is gratefully acknowledged.

8. Gimenz-Conti IB, La Bate M, Osterndorff E. p53 alterations in chemically induced hamster cheek pouch lesions. Mol Carcinog 1996;16(4):197-202.

9. Homann N, Jousimies-Somer H, Jokelainen K, Heine R, Salaspuro M. High acetaldehyde levels in saliva after ethanol consumption: methodological aspects and pathogenetic implications. Carcinogenesis 1997;18(9):1739-43.

10. Kabat GC, Winder EL. Type of alcoholic beverage and oral cancer. Int J Cancer 1989;43(2):190-4.

11. Korver KD, Graham SM, Hoffman HT, Mcculloch T, Funk GF. Liver function studies in the assessment of head and neck cancer patients. Head Neck 1995;17(6):531-4.

12. Lieber CS. Herman award lecture, 1993: a personal perspective on alcohol, nutrition, and the liver. Am J Clin Nutr 1993;58(3):430-42.

13. Maier H, Weidauer H, Zoller J, Seitz HK, Flentje M, Mall G, et al. Effect of chronic alcohol consumption on the morphology of the oral mucosa. Alcohol Clin Exp Res 1994;18(2):387-91.

14. Mascres C, Ming-Wen F, Joly JG. Morphologic changes of the esophageal mucosa in the rat after chronic alcohol ingestion. Exp Pathol 1984;25(3):147-53. 
Reis SRA, Espírito Santo AR, Andrade MGS, Sadigursky M. Cytologic alterations in the oral mucosa after chronic exposure to ethanol. Braz Oral Res 2006;20(2):97-102.

15. Muller P, Hepke B, Meldau U, Raabe G. Tissue damage in the rabbit oral mucosa by acute and chronic direct action of different alcohol concentrations. Exp Pathol 1983;24(2/3):171-81.

16. Obe G, Ristow H. Acetaldehyde, but not ethanol, induces sister chromatid exchanges in Chinese hamster cells in vitro. Mutat Res 1977;56(2):211-3.

17. Ogden GR. Alcohol and oral cancer. Alcohol 2005; 35(3):169-73

18. Ogden GR, Cowpe JG, Green M. Cytobrush and wooden spatula for oral exfoliative cytology. A comparison. Acta Cytol 1992;36(5):706-10.

19. Ogden GR, Wight AJ. Aetiology of oral cancer: alcohol. Br J Oral Maxillofac Surg 1998;36:247-51.

20. Reis SRA, Lima CR, Marchionni AMT, Setúbal MG. Risk factors for oral and oropharyngeal cancer. I. Alcohol, tobacco and other determinants. RPG 1997;4(1):127-32.

21. Schlecht NF, Franco EL, Pintos J, Negassa A, Kowalski LP, Oliveira BV, et al. Interaction between tobacco and alcohol consumption and the risk of the upper aero-digestive tract in Brazil. Am J Epidemiol 1999;150(11):1129-37.

22. Schlecht NF, Pintos J, Kowalski LP, Franco EL. Effect of type of alcoholic beverage on the risks of upper aerodigestive tract cancers in Brazil. Cancer Causes Control 2001;12(7):579-87.
23. Schottenfeld D. Alcohol as a co-factor in the etiology of cancer. Cancer 1979;43(5 Suppl):1962-6.

24. Schwartz JL, Gu X, Kittles RA, Baptiste A, Shklar G. Experimental oral carcinoma of tongue and buccal mucosa: possible biologic markers linked to cancers at two anatomic sites. Oral Oncol 1999;36(2):225-35.

25. Squier CA, Cox P, Wertz PW. Lipid content and water permeability of skin and oral mucosa. J Invest Dermatol 1991;96(1):123-6.

26. Tuyns AJ, Griciute LL. Carcinogenic substances in alcoholic beverages. Int Congr Ser 1980;484(1):130-5.

27. Wight AJ, Ogden GR. Possible mechanisms by which alcohol may influence the development of oral cancer: a review. Oral Oncol 1998;34(6):442-7.

28. Zain RB. Cultural and dietary risk factors of oral cancer and precancer - a brief overview. Oral Oncol 2001;37(3):205-10.

29. Ziegler RG. Alcohol-nutrient interactions in cancer etiology. Cancer 1986;58(8 Suppl):1942-8.

Received for publication on Aug 17, 2005

Sent for alterations on Dec 05, 2005

Accepted for publication on Mar 20, 2006 